Article

\title{
High Performance and Self-Humidifying of Novel Cross-Linked and Nanocomposite Proton Exchange Membranes Based on Sulfonated Polysulfone
}

\author{
Xinyu Li, Zhongxin Zhang, Zheng Xie, Xinrui Guo, Tianjian Yang, Zhongli Li, Mei Tu and Huaxin Rao*D
}

check for

updates

Citation: Li, X.; Zhang, Z.; Xie, Z.;

Guo, X.; Yang, T.; Li, Z.; Tu, M.; Rao,

H. High Performance and

Self-Humidifying of Novel

Cross-Linked and Nanocomposite

Proton Exchange Membranes Based

on Sulfonated Polysulfone.

Nanomaterials 2022, 12, 841 .

https://doi.org/10.3390/

nano12050841

Academic Editor: J. Karl Johnson

Received: 19 January 2022

Accepted: 1 March 2022

Published: 2 March 2022

Publisher's Note: MDPI stays neutral with regard to jurisdictional claims in published maps and institutional affiliations.

Copyright: (C) 2022 by the authors. Licensee MDPI, Basel, Switzerland. This article is an open access article distributed under the terms and conditions of the Creative Commons Attribution (CC BY) license (https:// creativecommons.org/licenses/by/ $4.0 /)$.
College of Chemistry and Materials Science, Jinan University, Guangzhou 510632, China; a1563927622@163.com (X.L.); jnuzwb2022@163.com (Z.Z.); xiez8700778@163.com (Z.X.); guoxinrui99@163.com (X.G.); jnusirui@163.com (T.Y.); oytxm@stu2020.jnu.edu.cn (Z.L.); tumei@jnu.edu.cn (M.T.) * Correspondence: traohx@jnu.edu.cn

\begin{abstract}
The introduction of inorganic additive or nanoparticles into fluorine-free proton exchange membranes (PEMs) can improve proton conductivity and have considerable effects on the performance of polymer electrolyte membrane fuel cells. Based on the sol-gel method and in situ polycondensation, novel cross-linked PEM and nanocomposite PEMs based on a sulfonated polysulfone (SPSU) matrix were prepared by introducing graphene oxide (GO) polymeric brushes and incorporating $\mathrm{Pt}-\mathrm{TiO}_{2}$ nanoparticles into an SPSU matrix, respectively. The results showed that the incorporation of $\mathrm{Pt}-\mathrm{TiO}_{2}$ nanoparticles could obviously enhance self-humidifying and thermal stability. In addition, GO polymer brushes fixed on polymeric PEM by forming a cross-linked network structure could not only solve the leakage of inorganic additives during use and compatibility problem with organic polymers, but also significantly improve proton conductivity and reduce methanol permeability of the nanocomposite PEM. Proton conductivity, water uptake and methanol permeability of the nanocomposite PEM can be up to $6.93 \mathrm{mS} \mathrm{cm}^{-1}, 46.58 \%$ and be as low as $1.4157 \times 10^{-6} \mathrm{~cm}^{2} \mathrm{~s}^{-1}$, respectively, which represent increases of about $70 \%$, about $22 \%$ and a decrease of about $40 \%$, respectively, compared with that of primary SPSU. Therefore, the synergic action of the covalent cross-linking, GO polymer brush and nanoparticles can significantly and simultaneously improve the overall performance of the composite PEM.
\end{abstract}

Keywords: fuel cells; proton exchange membrane; polymer brush; sulfonated polysulfone; graphene oxide; self-humidifying; nanoparticles

\section{Introduction}

Proton exchange membrane (PEM) are considered as the "heart" of the proton exchange membrane fuel cell (PEMFC), and its properties impact heavily on the performance, cost and even lifespan of PEMFC [1-5]. Perfluorosulfonic acid polymers such as Nafion are the most widely accepted and commercialized membranes to date that are used as PEM. However, conductivity loss at high temperatures, deficient membrane durability and methanol crossover through the membrane, which causes DMFC performance reduction, inhibit their use in large scale DMFC applications [6,7]. At present, the fluorine-free sulfonated aromatic PEMs have received tremendous attention due to their lower cost, higher hydrophilic ability and simpler preparation processing compared to that of the commercial Nafion [8-11]. Therefore, sulfonated polysulfone (SPSU) PEM, which are known as one of the most promising PEM without containing fluorine, are being widely studied because of excellent mechanical properties, good film-forming ability and low cost [12-15]. However, the thermal stability, chemical stability, water retention capacity and proton conductivity of the sulfonated polysulfone PEM should be further enhanced because of the low dissociation ability between carbon bonds and hydrogen bonds [16,17]. 
Sulfonated polysulfone PEMs only made of a single material can hardly meet the high requirements of PEMFC in all aspects [18,19]. So, the application of composite materials composed of two or more materials with multiple properties has been widely studied in recent years [20-24]. For example, the introduction of inorganic additives into polymeric PEMs is a simple and effective way to develop some properties of PEMFC under high temperature, low humidity or no humidity conditions. Some inorganic additives $\left(\mathrm{SiO}_{2}\right.$, $\mathrm{ZrO}_{2}, \mathrm{TiO}_{2}, \mathrm{Al}_{2} \mathrm{O}_{3}$ ) and some natural ores (montmorillonite, zeolite) with great moisturizing property, which are added into polymeric membrane, can enhance obviously moisturizing property and further keep proton conductivity under high temperature or low humidity condition [25-30]. However, the introduction of these inorganic additives with special construction can only develop a moisturizing property and physicochemical stability, but not obviously improve proton conductivity. In addition, the leakage problem of inorganic small molecules for PEMs will inevitably occur in the process of long-term use, due to simple physical doping.

Hence, the organic-inorganic composite membrane materials have received considerable attention in order to fix small molecules into a polymer matrix [31-34]. One efficient method is that in which the network structures formed by inorganic small molecules are dispersed in the polymeric matrix $[35,36]$. For example, a variety of alkoxy silane or alkyl titanate will form a three-dimensional network structure inside the membrane through a sol-gel reaction, which can effectively improve the stability and moisture retention ability of the membrane. However, the dispersion method cannot completely solve the leakage of inorganic materials, and will bring the compatibility problem between inorganic materials and polymer matrix. Sun synthesized $\mathrm{TiO}_{2}-\mathrm{SO}_{4}{ }^{2-}$ solid superacid nanoparticles by the sol-gel method and compounded with Nafion. The proton conductivity of the composite membrane is slightly lower than that of pure recast Nafion membrane, but it has low methanol permeability [37]. Another efficient method is that in which inorganic additives are fixed in the polymer matrix by some interaction (such as chemical bond) $[38,39]$. Wu prepared hybrid acid-base polymer membranes by blending sulfonated poly(2,6-dimethyl1,4-phenylene oxide) with (3-aminopropyl)triethoxysilane through a sol-gel process. The acid-base interaction improved not only the membrane homogeneity and thermal stability but also the mechanical strength and flexibility [40]. Of course, some special inorganic additives (such as phosphate) which form hardly network structure or chemical bonding with a polymeric matrix can form an acid-base interaction with an alkaline polymer matrix through static electricity [41,42]. Yu prepared high PA-doped paratactic PBI polymer membranes from PPA solution by sol-gel method. The composite membrane obtained by this method has a higher proton conductivity [43].

The aim of this study is developing a novel nanocomposite membrane using functionalized graphene oxide (GO) and $\mathrm{Pt}_{-} \mathrm{TiO}_{2}$ nanoparticles in order to solve the leakage of the inorganic additives and overcome the trade-off effect between proton conductivity and moisturizing property. Herein, a functionalized GO polymeric brushes (FPGO) was first synthesized by the sol-gel method and the hydrosilylation reaction and then was used to modify the SPSU matrix by in situ polycondensation. Then, Pt nanoparticles were deposited on $\mathrm{TiO}_{2}$ by redox method to form $\mathrm{Pt}_{\mathrm{tiO}} \mathrm{TiO}_{2}$ nanoparticles. Finally, a novel nanocomposite PEM with the cross-linked network structures was fabricated by introducing GO polymer brush and incorporating $\mathrm{Pt}_{-} \mathrm{TiO}_{2}$ nanoparticles as additives into the modified SPSU matrix.

\section{Materials and Methods}

\subsection{Materials}

Titanium dioxide $(50 \mathrm{~nm})$, sodium borohydride, sulfonated polysulfone (SPSU, MW $=80,000$, degree of sulfonation $=50 \%$, distribution index $=2$ ) were all obtained from Sigma-Aldrich. Graphene oxide (GO) was purchased from Suzhou Hengqiu Technology. Vinylmethyldimethoxysilane (VMDMO), 4-chlorostyrene, methanol and absolute ethanol were all provided from Adamas; 2,4,6,8-Tetramethylcyclotetrasiloxane $\left(\mathrm{D}_{4}{ }^{\mathrm{H}}\right)$ and chloroplatinic acid catalyst were supplied by Chengdu Organic Silicon Research, China. 
$\mathrm{N}, \mathrm{N}$-dimethylacetamide (DMAc), hydrogen peroxide, sodium chloride, and ferrous sulfate were all purchased from Guangzhou Chemical Reagent Factory. Nafion 117 was received from Shanghai Sanlu Industrial Co., Ltd.

\subsection{Preparation of $G O$ Polymeric Brushes}

GO polymeric brushes, which were used as an additive for the nanocomposite membrane, were prepared by sol-gel method according to our previous research work [44]. In short, polymeric brushes-modified graphene oxide (PGO) was first synthesized by surface precipitation polymerization between vinylmethyldimethoxysilane (VMDMO) and GO nanosheets, at $65^{\circ} \mathrm{C}$, under magnetic stirring for $24 \mathrm{~h}$. Then, $\mathrm{D}_{4}{ }^{\mathrm{H}} / 4$-chlorostyrene cyclic cross-linker was prepared by the hydrosilylation process between $\mathrm{D}_{4}{ }^{\mathrm{H}}$ and 4-chlorostyrene at room temperature. Finally, functionalized GO polymeric brushes nanosheets (FPGO) were synthesized via hydrosilylation reaction between the cyclic cross-linker and PGO under rapid stirring and the catalytic action of chloroplatinic acid.

\subsection{Preparation of $\mathrm{Pt}-\mathrm{TiO}_{2}$ Nanoparticles}

$50 \mathrm{mg} \mathrm{TiO}{ }_{2}$ was dispersed in $50 \mathrm{~mL}$ deionized water under ultrasonication for $2 \mathrm{~h}$. An amount of $2 \mathrm{~mL}$ chloroplatinic acid solution was added into $\mathrm{TiO}_{2}$ dispersion liquid to form a mixture solution, followed by stirring vigorously at room temperature for $1 \mathrm{~h}$. An amount of $0.2 \mathrm{M} \mathrm{NaBH}_{4}$ solution was added drop by drop to the mixed solution under ice-water bath, and then stirred at room temperature for $12 \mathrm{~h}$. Afterward, the product was separated by centrifugation and then washed repeatedly with anhydrous ethanol for three times. The final product was dried in vacuum at $70{ }^{\circ} \mathrm{C}$ for $6 \mathrm{~h}$ to obtain the gray-black $\mathrm{Pt}-\mathrm{TiO}_{2}$ nanoparticles.

\subsection{Preparation of the Cross-Linked PEM and Nanocomposite PEMs}

An amount of $2.0 \mathrm{~g}$ SPSU was dissolved in $8.5 \mathrm{~mL}$ DMAc under stirring at $40{ }^{\circ} \mathrm{C}$. An amount of $20.0 \mathrm{mg}$ FPGO was dispersed in $10.5 \mathrm{~mL}$ DMAc under ultrasonication for $2 \mathrm{~h}$, then the FPGO suspension was added into the SPSU solution. Then, the mixed solution was stirred for $0.5 \mathrm{~h}$ to form the evenly solution and refluxed at $100{ }^{\circ} \mathrm{C}$ for $20 \mathrm{~h}$. Through the condensation reaction between the -OK terminal groups of SPSU and the 4chlorostyrene groups of FPGO, inorganic additives and polymer matrix can be cross-linked and FPGO/SPSU cross-linked membrane was prepared by solution-casting method.

After the above FPGO/SPSU solution was cooled to room temperature, the prepared $2.0 \mathrm{mg} \mathrm{Pt}-\mathrm{TiO}_{2}$ nanoparticles were added to the solution. After $0.5 \mathrm{~h}$ of ultrasonic treatment, the mixed solution was cast on the mold to form $\mathrm{Pt}_{-} \mathrm{TiO}_{2} / \mathrm{FPGO} / \mathrm{SPSU}$ nanocomposite PEM. The membrane was dried at $40{ }^{\circ} \mathrm{C}$ for $12 \mathrm{~h}$ to remove the residual solvent, followed by successively drying at $90^{\circ} \mathrm{C}$ for $12 \mathrm{~h}$. After vacuum drying at $60^{\circ} \mathrm{C}$, the nanocomposite $\mathrm{PEM}$ with $0.1 \mathrm{wt} . \% \mathrm{Pt}-\mathrm{TiO}_{2}$ content was obtained. The prepared nanocomposite PEMs were designated as $\mathrm{Pt}_{-} \mathrm{TiO}_{2}$ /FPGO/SPSU-X, where $\mathrm{X}$ was the weight ratio percentage of $\mathrm{Pt}_{-\mathrm{TiO}}$ nanoparticles to $\mathrm{FPGO} / \mathrm{SPSU}$. As a comparison, pristine SPSU membrane and FPGO/SPSU membranes were also fabricated.

\subsection{Characterization}

\subsubsection{Characterization of $\mathrm{Pt}-\mathrm{TiO}_{2}$ Nanoparticles}

The X-ray diffraction patterns were collected by X-ray diffractometer (XRD, MiniFlex, Japanese Science, Tokyo, Japan), with the data collection range of $5^{\circ} \sim 60^{\circ}$ and the scanning speed of $5^{\circ} / \mathrm{min}$. The size and distribution of $\mathrm{Pt}-\mathrm{TiO}_{2}$ nanoparticles were determined by nano particle size and zeta potential analyzer (NANO ZS, Malvern, Malvern, UK). The morphology of $\mathrm{Pt}_{-} \mathrm{TiO}_{2}$ nanoparticles were observed by field emission transmission electron microscopy (TEM, JEOL 2100F, Japanese electron, Tokyo, Japan). 


\subsubsection{The Morphology of the Nanocomposite PEM}

Scanning electron microscopy (SEM, ULTRA 55, Germany ZEISS Company, Oberkochen, Germany) was used to observe the cross-sectional morphology of the membrane samples. Firstly, the membrane samples were frozen in liquid nitrogen, and then taken out and quickly broken. The membrane sample section was sprayed with gold under vacuum conditions.

\subsubsection{Measurement of Water Uptake (WU) and Swelling Ratio (SR)}

After vacuum drying at $60{ }^{\circ} \mathrm{C}$ for $24 \mathrm{~h}$, the weight of the membrane samples was measured to be $W_{d r y}(\mathrm{~g})$. Then, the membrane samples were immersed in deionized water for $48 \mathrm{~h}$, and then removed. The water on the membrane surface was wiped off with filter paper, and the mass of the membrane samples were weighed as $W_{\text {wet }}(\mathrm{g})$. The water uptake (WU) of the membrane samples is calculated by Equation (1).

The membrane sample was cut into a square of $1 \mathrm{~cm} \times 1 \mathrm{~cm}$ and the surface area was $A_{d r y}\left(\mathrm{~cm}^{2}\right)$. Then, the membrane samples were immersed in $20 \mathrm{~mL}$ deionized water and divided into four groups, which were stored at $30^{\circ} \mathrm{C}, 50^{\circ} \mathrm{C}, 70^{\circ} \mathrm{C}$ and $90{ }^{\circ} \mathrm{C}$ for $24 \mathrm{~h}$, respectively. After removal, the surface area of the membrane sample was $A_{\text {wet }}\left(\mathrm{cm}^{2}\right)$. The swelling ration (SR) of the membrane samples is calculated by Equation (2).

$$
\begin{gathered}
\text { Water Uptake }(\%)=\frac{W_{w e t}-W_{d r y}}{W_{d r y}} \times 100 \% \\
\text { Swelling Ration(\%) }=\frac{A_{w e t}-A_{d r y}}{A_{d r y}} \times 100 \%
\end{gathered}
$$

where $W_{d r y}$ and $A_{d r y}$ are the weight and the surface area of the dry membranes, and $W_{\text {wet }}$ and $A_{\text {wet }}$ are the weight and the surface area of the wet membranes, respectively.

\subsubsection{Measurement of Ion Exchange Capacity (IEC)}

Ion exchange capacity (IEC) of the membrane samples was determined by acid-base titration. Firstly, membrane samples were soaked in $1 \mathrm{M} \mathrm{HCl}$ solution and heated to $70{ }^{\circ} \mathrm{C}$ for $1 \mathrm{~h}$, which changed them into the $\mathrm{H}^{+}$form. The samples were then washed with distilled water several times to remove excess $\mathrm{HCl}$, and right after that they were soaked in boiling water for $1 \mathrm{~h}$, which confirmed the stability of membranes in hydrolytic conditions. In the next step, we took the samples in $50 \mathrm{~mL}$ of $1 \mathrm{M} \mathrm{NaCl}$ solution heated to $40^{\circ} \mathrm{C}$ and equilibrated for at least $24 \mathrm{~h}$ to replace the protons by sodium ions. The remaining solution was titrated with $0.01 \mathrm{M} \mathrm{NaOH}$ solution using phenolphthalein as an indicator. IEC of the membrane samples is calculated by Equation (3).

$$
\mathrm{IEC}=\frac{C_{\mathrm{NaOH}} \times V_{\mathrm{NaOH}}}{W_{d r y}} \times 100 \%
$$

where $W_{d r y}$ is the weight of dry membrane (g), $V_{\mathrm{NaOH}}$ is the volume of $\mathrm{NaOH}$ solution consumed by titration $(\mathrm{mL})$, and $\mathrm{C}_{\mathrm{NaOH}}$ is the concentration of $\mathrm{NaOH}$ solution $(\mathrm{mol} / \mathrm{L})$.

\subsubsection{Measurement of Thermal Stability}

The thermal properties of the nanocomposite membranes were evaluated by thermogravimetric analyzer (TGA, TG209F3, Netzsch, Serb, Germany) at $10{ }^{\circ} \mathrm{C} / \mathrm{min}$ from $40{ }^{\circ} \mathrm{C}$ to $800{ }^{\circ} \mathrm{C}$.

\subsubsection{Measurement of Mechanical Properties}

The mechanical properties of the nanocomposite membrane were tested using a material tensile tester (SHMADZU AG-1, Shimadzu, Kyoto City, Japan). The tensile rate was $2 \mathrm{~mm} / \mathrm{min}$, and each sample was tested three times in parallel. 


\subsubsection{Measurement of Oxidation Stability}

The nanocomposite membrane was immersed in $20 \mathrm{~mL}$ Fenton reagent $\left(2 \mathrm{mg} / \mathrm{L} \mathrm{FeSO}_{4}\right.$ in $3 \% \mathrm{H}_{2} \mathrm{O}_{2}$ ), followed by placing in an oven at $80{ }^{\circ} \mathrm{C}$ to observe the decomposition of the samples with different times.

\subsubsection{Measurement of Proton Conductivity}

Proton conductivity of the nanocomposite membrane was measured using an electrochemical workstation (Versa Stat 3, AMETEK, Shanghai, China). The test method was double-electrode AC impedance spectroscopy. The perturbation voltage was $10 \mathrm{mV}$ and the test frequency was $1 \mathrm{~Hz} 10^{5} \mathrm{~Hz}$. Proton conductivity of the membrane samples is calculated by Equation (4).

$$
\sigma=\frac{L}{R \times A}
$$

where $\sigma(\mathrm{S} / \mathrm{cm})$ is the proton conductivity of the membranes, $L(\mathrm{~cm})$ is the distance between the two electrodes, $R(\Omega)$ is the impedance of the membrane samples measured under the AC impedance method, and $A\left(\mathrm{~cm}^{2}\right)$ is the cross-sectional area of the membrane samples.

\subsubsection{Measurement of Methanol Permeability and Selectivity}

In the glass diffusion cell, the methanol permeability of various membrane samples was carried out at $30^{\circ} \mathrm{C}$, and the glass diffusion cell was composed of two compartments separated by proton exchange membrane. Prehydrate the membrane for $24 \mathrm{~h}$ and then clamp it between two diffusion chambers. The compartment $A$ was first filled with $50 \mathrm{wt} . \%$ methanol aqueous solution, and the compartment $B$ was first filled with deionized water. The methanol concentration in compartment $B$ was measured immediately during the diffusion process using a digital refractometer (ABBE WYA 2WAJ, Shanghai, China). The methanol permeability of the composite membrane is calculated by Equation (5).

$$
P=\frac{S V_{B} L}{A C_{A}}
$$

where $V_{B}$ is the volume of the solution in the $B$ compartment $\left(\mathrm{cm}^{3}\right), L$ is the thickness of the membrane sample $(\mathrm{cm}), A$ is the contact area between the membrane sample and the solution $\left(\mathrm{cm}^{2}\right)$, and $C_{A}$ is the molar concentration of the methanol solution in the $\mathrm{A}$ compartment $(\mathrm{mol} / \mathrm{L}), S$ is the slope of the molar concentration-time curve of methanol solution in compartment $B$.

The comprehensive performance of membranes was evaluated by selectivity ( $\beta, \mathrm{S} s$ $\mathrm{cm}^{-3}$ ), which is defined as:

$$
\beta=\frac{\sigma}{P}
$$

\section{Results}

\subsection{Preparation Process of the Cross-Linked PEM and the Nanocomposite PEMs}

Graphene oxide (GO) representing 2D carbonaceous materials have received considerable attention, due to high performance [45]. It has been demonstrated that the protons can be transferred by the carboxylic acid groups along edges of $\mathrm{GO}$ and epoxy groups on the surface of GO [46]. Therefore, we develop a novel nanocomposite PEM by using functionalized $\mathrm{GO}$ and $\mathrm{Pt}-\mathrm{TiO}_{2}$ nanoparticles in order to solve the leakage of the inorganic additives and overcome the trade-off effect between proton conductivity and moisturizing property.

The preparation process of FPGO and FPGO/SPSU is shown in Figure 1. Firstly, the cyclic silane cross-linked agent $\left(\mathrm{D}_{4}{ }^{\mathrm{H}} / 4\right.$-chlorostyrene) containing active $\mathrm{Si}-\mathrm{H}$ bond was synthesized by hydrosilylation of $\mathrm{D}_{4}{ }^{\mathrm{H}}$ and p-chlorostyrene (4-chlorostyrene) with the molar ratio of 3:1 under the chloroplatinic acid catalysis. Then, linear VMDMO was grafted onto the surface of GO sheet by the sol-gel method to prepare the GO polymer brush with a sandwich structure. Secondly, the functional GO polymer brushes (FPGO) were prepared by addition reaction between $\mathrm{D}_{4} \mathrm{H}$ /4-chlorostyrene cross-linked agent and PGO polymer 
brushes containing double bond. Finally, FPGO/SPSU cross-linked PEM was prepared by in situ polycondensation of SPSU terminal OK group and chlorobenzene group $(\mathrm{Cl})$ on FPGO surface.
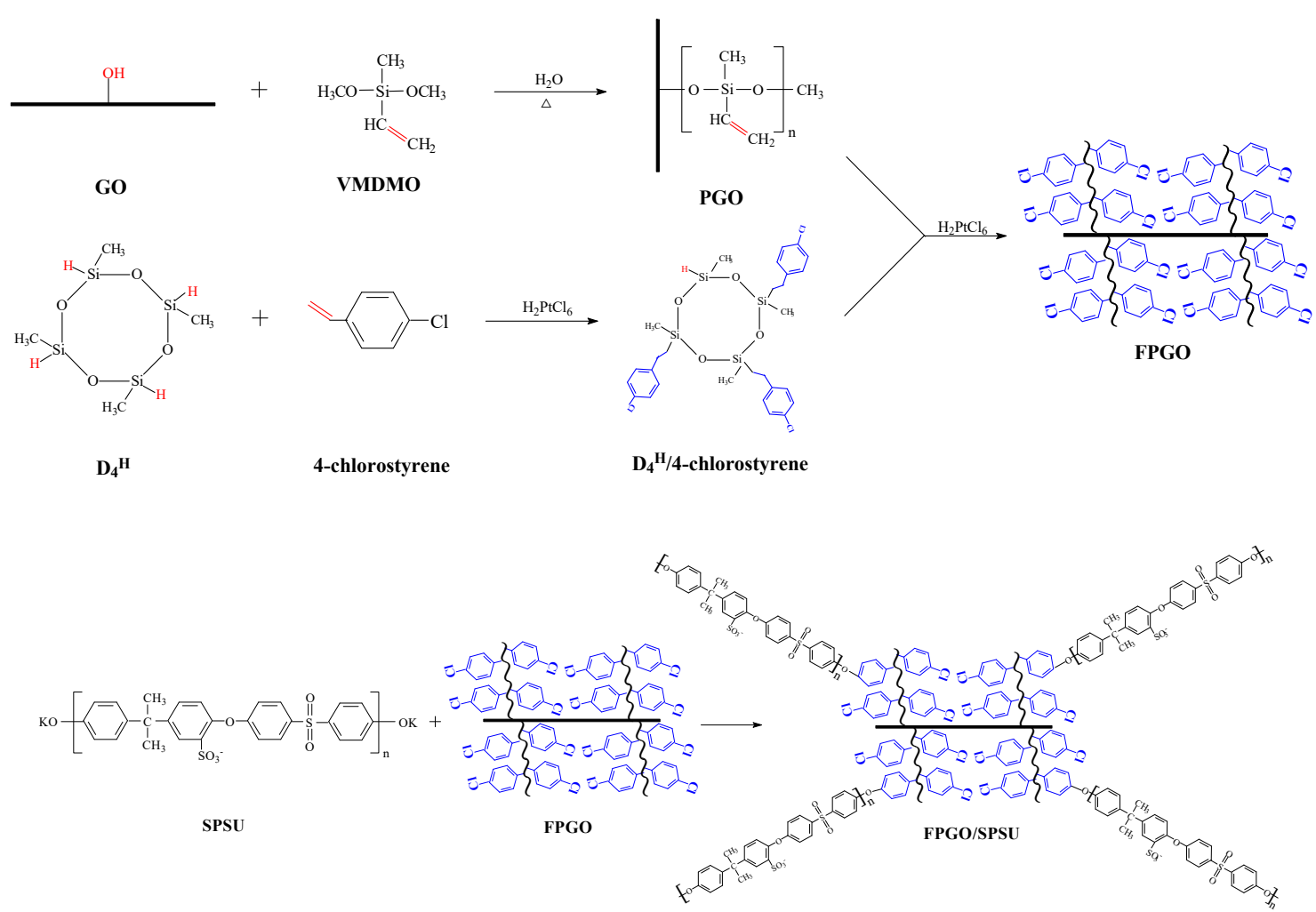

Figure 1. Schematic representation of preparation process of FPGO and FPGO/SPSU cross-linked PEM.

In order to improve the self-humidifying performance of SPSU matrix membrane, $\mathrm{Pt}$ nanoparticles were first deposited on nano- $\mathrm{TiO}_{2}$ by redox method using $\mathrm{NaBH}_{4}$ as a catalyst to prepare $\mathrm{Pt}-\mathrm{TiO}_{2}$ nanoparticles, followed by dispersing in FPGO/SPSU solution. Finally, $\mathrm{Pt}-\mathrm{TiO}_{2} / \mathrm{FPGO} / \mathrm{SPSU}$ nanocomposite $\mathrm{PEMs}$ with different $\mathrm{Pt}-\mathrm{TiO}_{2}$ contents were prepared by impregnation method and solution casting method (shown in Figure 2).

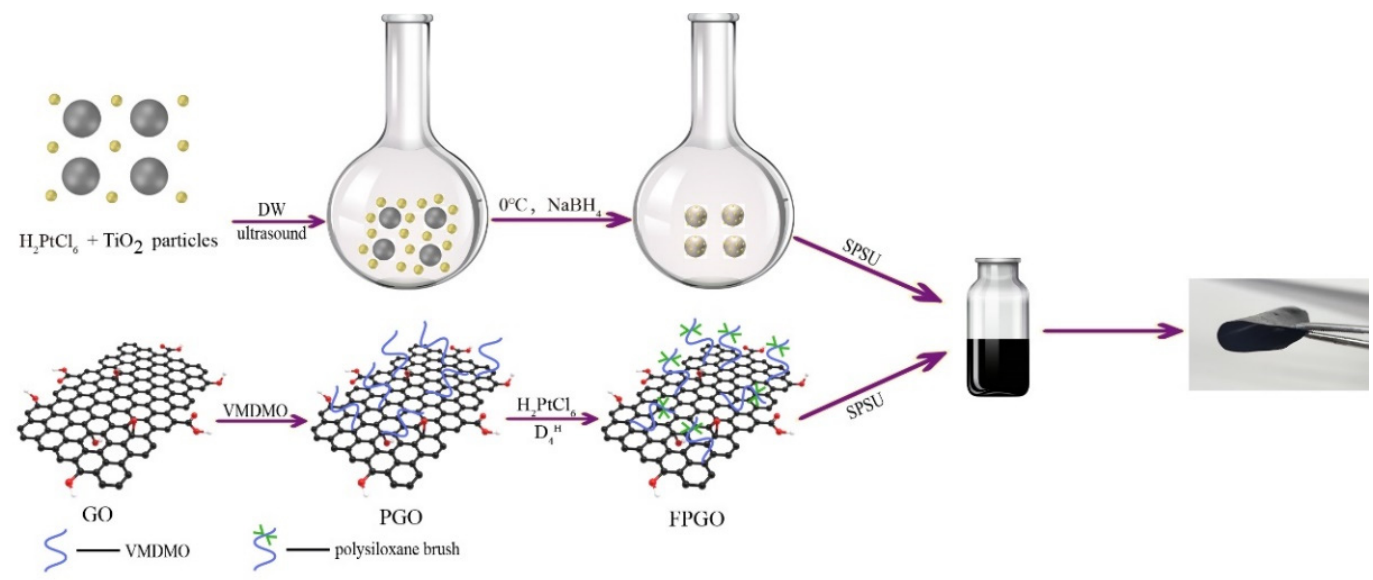

Figure 2. Schematic illustration of the fabrication process for $\mathrm{Pt}_{-} \mathrm{TiO}_{2} / \mathrm{FPGO} / \mathrm{SPSU}$ nanocomposite PEM.

\subsection{Characterization of $\mathrm{Pt}-\mathrm{TiO}_{2}$ Nanoparticles}

The XRD patterns of $\mathrm{Pt}-\mathrm{TiO}_{2}$ nanoparticles and nano $\mathrm{TiO}_{2}$ are shown in Figure $3 \mathrm{a}$. In the XRD pattern of $\mathrm{Pt}-\mathrm{TiO}_{2}$, the diffraction peak intensity of $\mathrm{TiO}_{2}$ is obviously weakened due to the incorporation of $\mathrm{Pt}$, and the diffraction peaks of $\mathrm{Pt}(111),(200)$ and (220) crystal planes 
appear at $2 \theta=40^{\circ}, 2 \theta=46^{\circ}$ and $2 \theta=67.5^{\circ}$, respectively. This indicates that Pt nanoparticles are successfully incorporated into nano $\mathrm{TiO}_{2}$ to form $\mathrm{Pt}-\mathrm{TiO}_{2}$ nanoparticles. The average particle sizes of $\mathrm{Pt}_{-} \mathrm{TiO}_{2}$ nanoparticles (about $80 \mathrm{~nm}$ ) measured by the nanoparticle size analyzer are larger than these of nano $\mathrm{TiO}_{2}$ (about $2 \mathrm{~nm}$ ). In addition, the TEM images of $\mathrm{Pt}_{-} \mathrm{TiO}_{2}$ nanoparticles (Figure 3b) indicates further that Pt nanoparticles are uniformly dispersed on the surface of $\mathrm{TiO}_{2}$ particles and the interface between particles.
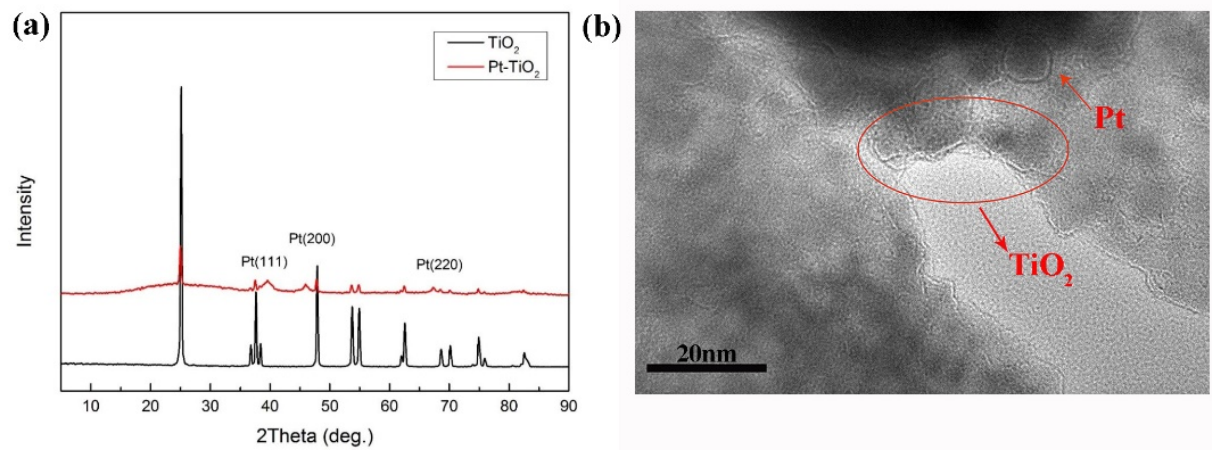

Figure 3. X-ray diffraction pattern (a) and TEM image (b) of $\mathrm{Pt}^{-\mathrm{TiO}_{2}}$ nanoparticles.

\subsection{Characterization of the Cross-Linked PEM and the Nanocomposite PEMs \\ 3.3.1. Surface Morphology}

The cross-sectional morphologies of FPGO/SPSU cross-linked PEM and Pt-TiO $/$ FPGO/ SPSU-X nanocomposite PEMs are shown in Figure 4. It can be observed that evident aggregation and phase separation did not appear and $\mathrm{Pt}-\mathrm{TiO}_{2}$ nanoparticles were uniformly distributed in the nanocomposite PEMs. If aggregation and phase separation occur, obvious fibrous and granular crystals appear on the section (as shown by red arrows in Figure 4d). This is because FPGO contribute to a stronger cross-linked interaction with SPSU compared with the pristine GO, which weakens the surface tension of GO and avoids micro-phase separation. When the content of $\mathrm{Pt}-\mathrm{TiO}_{2}$ nanoparticles is $0.1 \%$, the multilayer fold layer structure of the nanocomposite PEM can be clearly observed from the section diagram, indicating that FPGO and $\mathrm{Pt}_{-} \mathrm{TiO}_{2}$ nanoparticles have good compatibility with SPSU matrix. However, when the $\mathrm{Pt}-\mathrm{TiO}_{2}$ content is increased up to $3 \mathrm{wt} . \%$, some fibrous and granular crystals appeared on the cross section. The rough morphology and partial agglomeration of the inorganic additives is most likely caused by the excessive Pt nanoparticles affecting the dispersion of $\mathrm{TiO}_{2}$ and FPGO in SPSU.

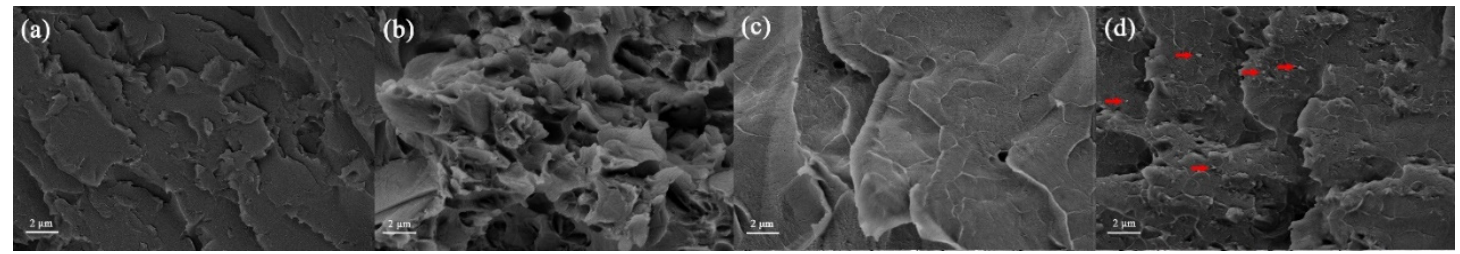

Figure 4. SEM images of the membranes: (a) FPGO/SPSU, (b) Pt-TiO $2 /$ FPGO/SPSU-1, (c) Pt$\mathrm{TiO}_{2}$ /FPGO/SPSU-2, (d) Pt-TiO $/$ /FPGO/SPSU@-3.

\subsubsection{Mechanical Properties}

As indicated in Table 1, the cross-linked network structure and incorporation of Pt$\mathrm{TiO}_{2}$ nanoparticles have effect on the mechanical properties of all the membranes. When incorporating of $\mathrm{Pt}_{-} \mathrm{TiO}_{2}$ nanoparticles the nanocomposite PEMs, the elastic deformation resistance can be effectively improved while the tensile strength decreased to a certain extent. This is because the incorporation of $\mathrm{Pt}-\mathrm{TiO}_{2}$ nanoparticles dispersed between the SPSU matrix and the lamellar structure of GO hinder the movement of the polymer chain segment. In addition, the increase in $\mathrm{Pt}_{-} \mathrm{TiO}_{2}$ contents will cause the aggregation of the 
inorganic additives and structural defects of the nanocomposite PEMs, which make it more prone to stress concentration under stress and thereby decrease the strength of the nanocomposite PEMs.

Table 1. Mechanical properties of all the membranes.

\begin{tabular}{cccc}
\hline PEM Samples & Young's Modulus (MPa) & Tensile Strength (MPa) & Elongation at Break (\%) \\
\hline Nafion 117 & $100.00^{\mathrm{a}}$ & $28.40^{\mathrm{a}}$ & $329^{\mathrm{a}}$ \\
\hline SPSU & 342.30 & 30.15 & 7.29 \\
FPGO/SPSU & 267.50 & 32.60 & 12.37 \\
$\mathrm{Pt}_{\mathrm{TiO}}$ /FPGO/SPSU-1 & 304.50 & 29.14 & 15.44 \\
$\mathrm{Pt}-\mathrm{TiO}_{2} / \mathrm{FPGO} / \mathrm{SPSU}-2$ & 671.10 & 30.90 & 13.81 \\
$\mathrm{Pt}_{\mathrm{TiO}}$ /FPGO/SPSU-3 & 258.05 & 25.44 & 12.82 \\
\hline
\end{tabular}

a According to ref. [47].

\subsubsection{Thermal Stability}

The thermal stability of the as-obtained membranes, which is important for the PEM lifetime, is determined by TGA and displayed in Figure 5. Both the FPGO/SPSU crosslinked PEM and the Pt-TiO 2 /FPGO/SPSU-X nanocomposite PEMs show similar decomposition processes with a three-step weight loss behavior. The first weight loss platform of the nanocomposite membrane appeared below $200{ }^{\circ} \mathrm{C}$, which was mainly caused by the volatilization of adsorbed water, bound water and residual solvent in the membranes. At this stage, the weight loss of the nanocomposite membrane was significantly greater than that of the cross-linked membrane, indicating that the incorporation of $\mathrm{Pt}_{-} \mathrm{TiO}_{2}$ nanoparticles could greatly improve the water retention capacity of the nanocomposite membrane. The second weight loss platform is in the range of $200 \sim 400{ }^{\circ} \mathrm{C}$, corresponding to the decomposition of sulfonic acid groups and several other functional groups in composite membrane. In this stage, the weight loss curve of the nanocomposite membrane did not change significantly, indicating that the incorporation of $\mathrm{Pt}-\mathrm{TiO}_{2}$ nanoparticles can lead to an improvement in the thermal stability of the nanocomposite membrane to a certain extent. The third weight loss platform starting from $400{ }^{\circ} \mathrm{C}$ was mainly caused by the decomposition of polymer main chains. In contrast, Nafion begins chemical decomposition at about $300{ }^{\circ} \mathrm{C}$, and major decomposition products in the range $355^{\circ} \mathrm{C}-560{ }^{\circ} \mathrm{C}$ were $\mathrm{HF}$, $\mathrm{SiF}_{4}$, carbonyl fluorides, and species exhibiting $\mathrm{C}-\mathrm{F}$ stretching vibrations [48]. Therefore, the cross-linked PEM and the nanocomposite PEMs are sufficiently stable below $200{ }^{\circ} \mathrm{C}$ and can meet the application of PEMFC.

\subsubsection{Oxidation Stability}

The morphologies of FPGO/SPSU cross-linked PEM and Pt- $\mathrm{TiO}_{2} / \mathrm{FPGO}_{\text {SPSU-X }}$ nanocomposite PEM immersed in Fenton reagent at $80^{\circ} \mathrm{C}$ for $210 \mathrm{~min}$ are shown in Figure 6 and Table 2. By observing the color of reagents in the sample bottle and the morphological changes of the membrane samples, it can be seen that the nanocomposite PEMs show good oxidation resistance when the cross-linked PEM was deformed and dissolved to different degrees. However, with an increase in the content of $\mathrm{Pt}_{-} \mathrm{TiO}_{2}$ nanoparticles within the nanocomposite PEMs, the hydrogen bond between GO and SPSU matrix is weakened by a large number of $\mathrm{Pt}_{-} \mathrm{TiO}_{2}$ nanoparticles dispersed in the polymer matrix, which make the polar groups in SPSU more vulnerable to the attack of -OH and -OOH radicals in Fenton reagent, and finally resulting in the decreased oxidation stability of the nanocomposite PEMs. 


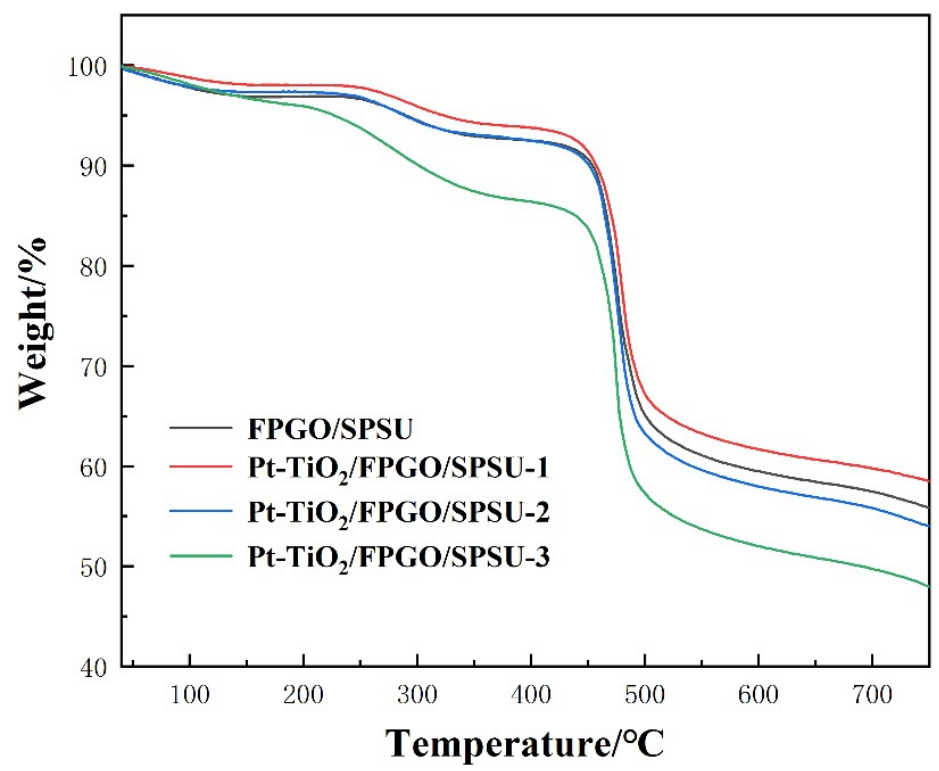

Figure 5. TGA curves of all the membranes.

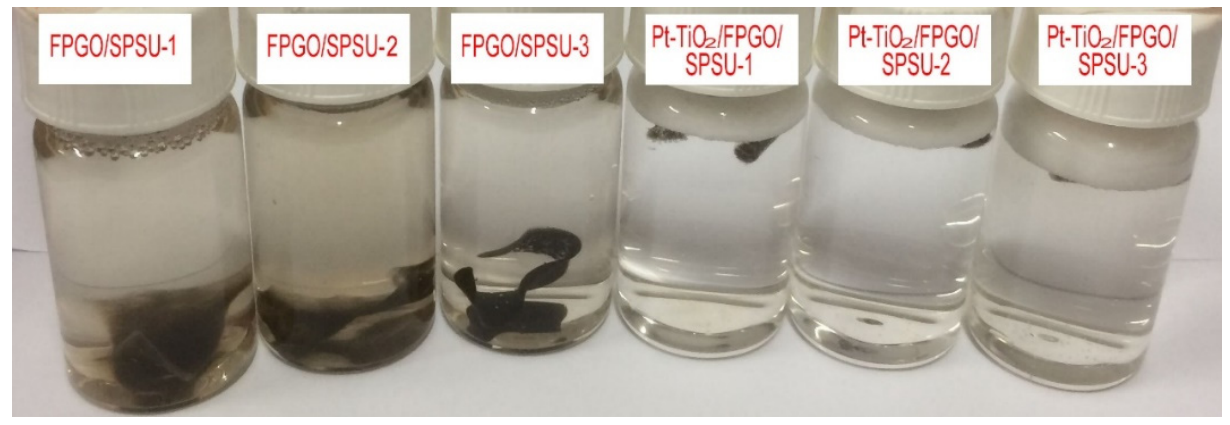

Figure 6. Photograph of all membranes immersed in Fenton reagent for $210 \mathrm{~min}$ at $80^{\circ} \mathrm{C}$.

Table 2. Oxidative stability of all the membranes.

\begin{tabular}{cccc}
\hline \multirow{2}{*}{ PEM Samples } & \multicolumn{3}{c}{ Oxidative Stability $^{\mathbf{a}}$ (min) } \\
\cline { 2 - 4 } & $\boldsymbol{\tau}_{\mathbf{1}}{ }^{\mathbf{b}}$ & $\boldsymbol{\tau}_{\mathbf{2}}{ }^{\mathbf{c}}$ & $\Delta=\boldsymbol{\tau}_{\mathbf{2}}-\boldsymbol{\tau}_{\mathbf{1}}$ \\
\hline Nafion 117 & $180^{\mathrm{d}}$ & $>960^{\mathrm{d}}$ & $>780^{\mathrm{d}}$ \\
$\mathrm{SPSU}$ & 75 & 120 & 45 \\
$\mathrm{FPGO} / \mathrm{SPSU}$ & 90 & 310 & 220 \\
$\mathrm{Pt}_{\mathrm{TiO}}$ /FPGO/SPSU-1 & 255 & 735 & 480 \\
$\mathrm{Pt}_{\mathrm{TiO}}$ /FPGO/SPSU-2 & 270 & 630 & 360 \\
$\mathrm{Pt}_{\mathrm{TiO}}$ /FPGO/SPSU-3 & 240 & 545 & 305 \\
\hline
\end{tabular}

${ }^{\text {a }}$ Measured at $80{ }^{\circ} \mathrm{C}$ in $3 \% \mathrm{H}_{2} \mathrm{O}_{2}$ containing $2 \mathrm{ppm} \mathrm{FeSO}_{4} \cdot{ }^{\mathrm{b}}$ The time when the membrane began to dissolve.

${ }^{c}$ The time when the membrane dissolved completely. ${ }^{\mathrm{d}}$ According to ref. [49].

\subsection{The Performance of the Cross-Linked PEM and the Nanocomposite PEMs}

3.4.1. Water Uptake, Swelling Ratio and Ion Exchange Capacity

WU and IEC of all the membranes are summarized in Table 3. As seen in the table, WU and IEC of FPGO/SPSU cross-linked PEM and $\mathrm{Pt}_{-T i O}$ /FPGO/SPSU-X nanocomposite PEMs are higher than that of the primary SPSU, indicating that the introduction of GO polymer brushes and the incorporation of $\mathrm{Pt}_{-} \mathrm{TiO}_{2}$ nanoparticles helps to increase hydrophilicity and free volume property of the membranes. However, WU and IEC increase initially and decrease afterwards with an increase in $\mathrm{Pt}_{-} \mathrm{TiO}_{2}$ nanoparticles contents. This is because more $\mathrm{Pt}-\mathrm{TiO}_{2}$ nanoparticles cover the sulfonic groups in the nanocomposite membrane, 
resulting in a decrease in the number of effective sulfonic groups. The relatively high water absorption is not necessarily a good characteristic, because it will produce mechanical stress during the fuel cell operation.

Table 3. WU, IEC and SR of all the membranes.

\begin{tabular}{ccccccc}
\hline \multirow{2}{*}{ Membrane Samples } & WU (\%) & IEC (mmol/g) & \multicolumn{3}{c}{ SR (\%) } \\
\cline { 4 - 7 } & & & $\mathbf{3 0}^{\circ} \mathbf{C}$ & $\mathbf{5 0}^{\circ} \mathbf{C}$ & $\mathbf{7 0}^{\circ} \mathbf{C}$ & $\mathbf{9 0}^{\circ} \mathbf{C}$ \\
\hline Nafion 117 & $35.60^{\mathrm{a}}$ & $0.91{ }^{\mathrm{a}}$ & $13.02^{\mathrm{b}}$ & $15.88^{\mathrm{b}}$ & $17.52^{\mathrm{b}}$ & $20.16^{\mathrm{b}}$ \\
SPSU & 38.12 & 1.52 & 6.02 & 13.73 & 20.42 & 169.72 \\
FPG/SPSU & 45.89 & 1.83 & 8.85 & 12.62 & 14.93 & 154.39 \\
$\mathrm{Pt}_{\mathrm{TiO}}$ /FPGO/SPSU-1 & 46.58 & 1.91 & 9.16 & 13.37 & 15.87 & 172.52 \\
$\mathrm{Pt}_{\mathrm{TiO}}$ /FPGO/SPSU-2 & 47.85 & 2.23 & 9.21 & 14.25 & 16.74 & 187.36 \\
$\mathrm{Pt}_{\mathrm{TiO}}$ /FPGO/SPSU-3 & 47.81 & 1.97 & 9.47 & 14.76 & 15.31 & 166.27 \\
\hline
\end{tabular}

a According to ref. [47]. ${ }^{\mathrm{b}}$ According to ref. [50].

SR of all the membranes at an elevated temperature are also shown in Table 3. SR of the nanocomposite PEM at $30^{\circ} \mathrm{C}$ slightly increases with the increase in $\mathrm{Pt}$ - $\mathrm{TiO}_{2}$ nanoparticles content. However, the SR of $\mathrm{Pt}_{-} \mathrm{TiO}_{2} / \mathrm{FPGO} / \mathrm{SPSU}-3$ membrane at $70{ }^{\circ} \mathrm{C}$ and $90{ }^{\circ} \mathrm{C}$ is smaller than that of $\mathrm{Pt}_{-} \mathrm{TiO}_{2} / \mathrm{FPGO} / \mathrm{SPSU}-1$ and $\mathrm{Pt}-\mathrm{TiO}_{2} / \mathrm{FPGO} / \mathrm{SPSU}-2$ nanocomposite membrane.

\subsubsection{Proton Conductivity}

Figure 7a presents the temperature-dependent proton conductivity of the primary SPSU membrane, the FPGO/SPSU membrane and the nanocomposite membranes. All membranes exhibit a pronounced increase in proton conductivities with increasing temperature from $30^{\circ} \mathrm{C}$ to $90^{\circ} \mathrm{C}$ because of the thermally activated characteristic of the proton transportation. Arrhenius plots of proton conductivity of all membranes are also depicted in Figure $7 b$. For a purely Grotthuss mechanism, the expected activation energy is in the range of 14.3 to $39.8 \mathrm{~kJ} / \mathrm{mol}$, which matches the experimentally determined range of 15.31 to $22.96 \mathrm{~kJ} / \mathrm{mol}$. It can also be seen that the Arrhenius plot of all membranes shows a positive temperature-conductivity dependence, revealing the thermal activity process of proton conductivity. The significantly improved proton conductivity with elevated temperature can be attributed to the combined effect of the following factor: the increase in temperature will promote the movement of macromolecular chains and the absorption of water molecules in membrane materials.

(a)

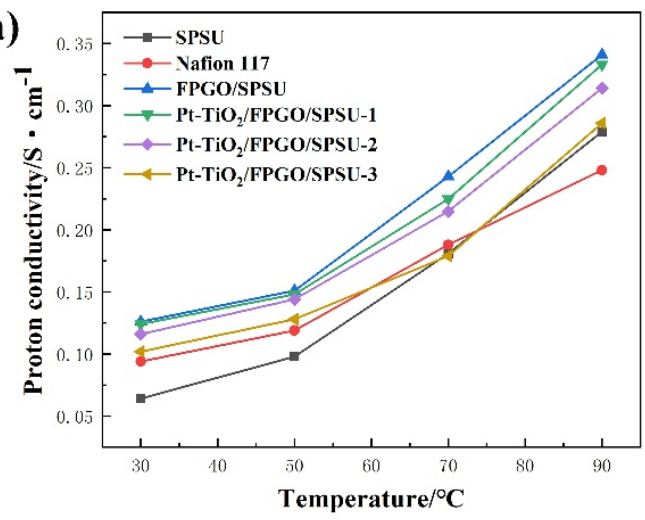

(b)

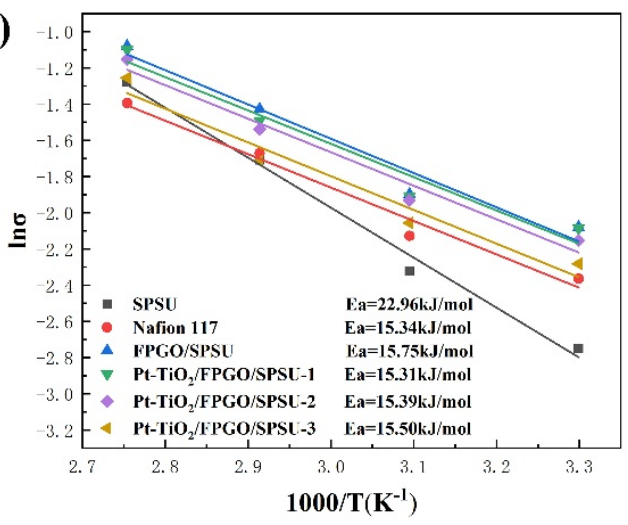

Figure 7. The temperature-dependent proton conductivity (a) and Arrhenius plots of proton conductivity (b) for all the membranes. (The data of Nafion 117 in Figure 7 are from ref. [44].)

However, the incorporation of $\mathrm{Pt}_{-} \mathrm{TiO}_{2}$ nanoparticles will slightly decrease the proton conductivity of the nanocomposite membrane to a certain extent. At the same time, the proton conductivity of the nanocomposite membrane obviously reduces with an increase 
in the content of incorporated $\mathrm{Pt}-\mathrm{TiO}_{2}$ nanoparticles. Although $\mathrm{Pt}_{-} \mathrm{TiO}_{2}$ nanoparticles can improve the water uptake and ion exchange capacity of the nanocomposite membranes to a certain extent, the uneven distribution of the nanoparticles may affect the continuity of the proton transport channel formed by sulfonate ion clusters. In addition, the incorporation of $\mathrm{Pt}_{-} \mathrm{TiO}_{2}$ nanoparticles will occupy more free volume of the SPSU matrix, which does not benefit the formation of proton transport channels.

Herein, the proton conductivity of PEMs is strongly dependent on their channel structures and water uptake [51]. However, due to the chemical and surface properties of GO polymer brush and $\mathrm{Pt}-\mathrm{TiO}_{2}$ nanoparticles as additives, the proton conductivity mechanism of the nanocomposites PEMs is becoming complicated and necessary to further investigate. Figure 8 indicates the mechanism of promoting proton transport in the nanocomposite PEMs. The hydroxyl groups on the $\mathrm{Pt}_{-} \mathrm{TiO}_{2}$ surface can interact with water molecules through hydrogen bonds, which is helpful for the formation of hydrophilic channels, so that the proton transfer can be quickly carried out in the form of hydrated hydrogen ions through the diffusion mechanism. Moreover, the hydrogen bond interaction between $\mathrm{Pt}_{-} \mathrm{TiO}_{2}$ and $\mathrm{GO}$ polymer brush as well as cross-linked polymer matrix also provides proton transport channels.

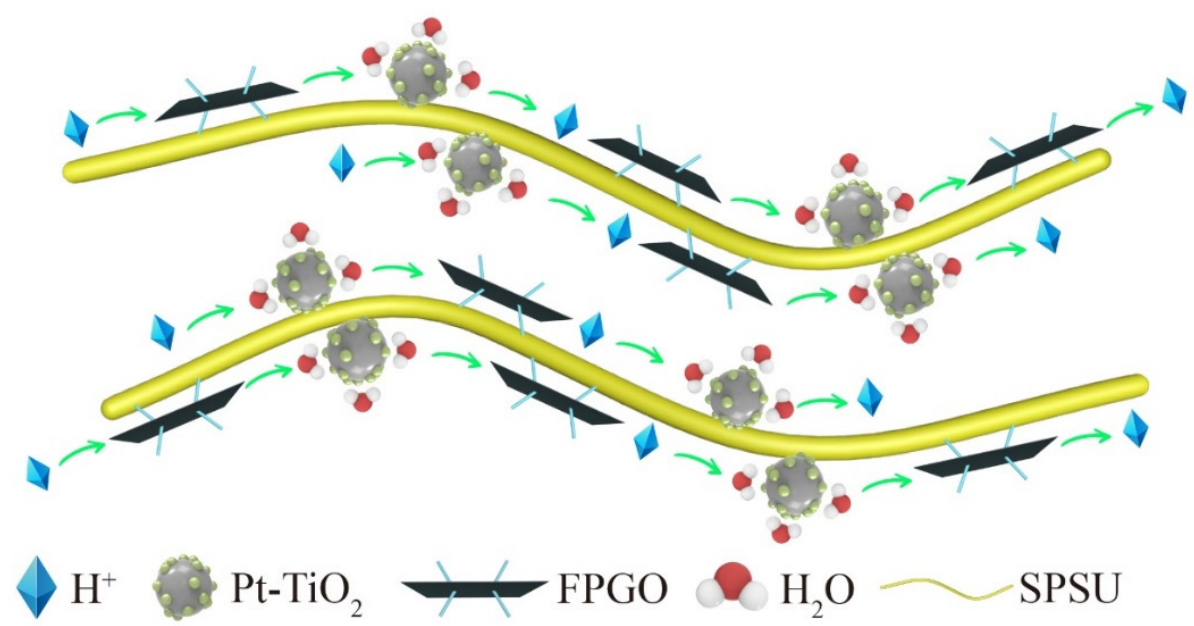

Figure 8. Diagram of proton conductivity mechanism in the nanocomposite PEM.

Figure 9 indicates the operating time-dependent proton conductivity of the primary SPSU membrane, the cross-linked PEM and the nanocomposite PEMs at $60^{\circ} \mathrm{C}$ and room humidity (RH) of $39 \%$. The membrane holder was suddenly heated to $60{ }^{\circ} \mathrm{C}$ while still in contact with ambient air (39\% RH) to induce dehydration, which was monitored by membrane conductivity measurements. Compared with the primary SPSU membrane, the cross-linked membrane and the nanocomposite membranes exhibit higher proton conductivity, indicating that the nanocomposite membrane has better water retention capacity under high temperature conditions. This is because the hydrogen bonds between the hydroxyl groups on the surface of the nanoparticles and the water molecules in the system inhibit the movement of water, thereby reduce the evaporation rate of water molecules. 


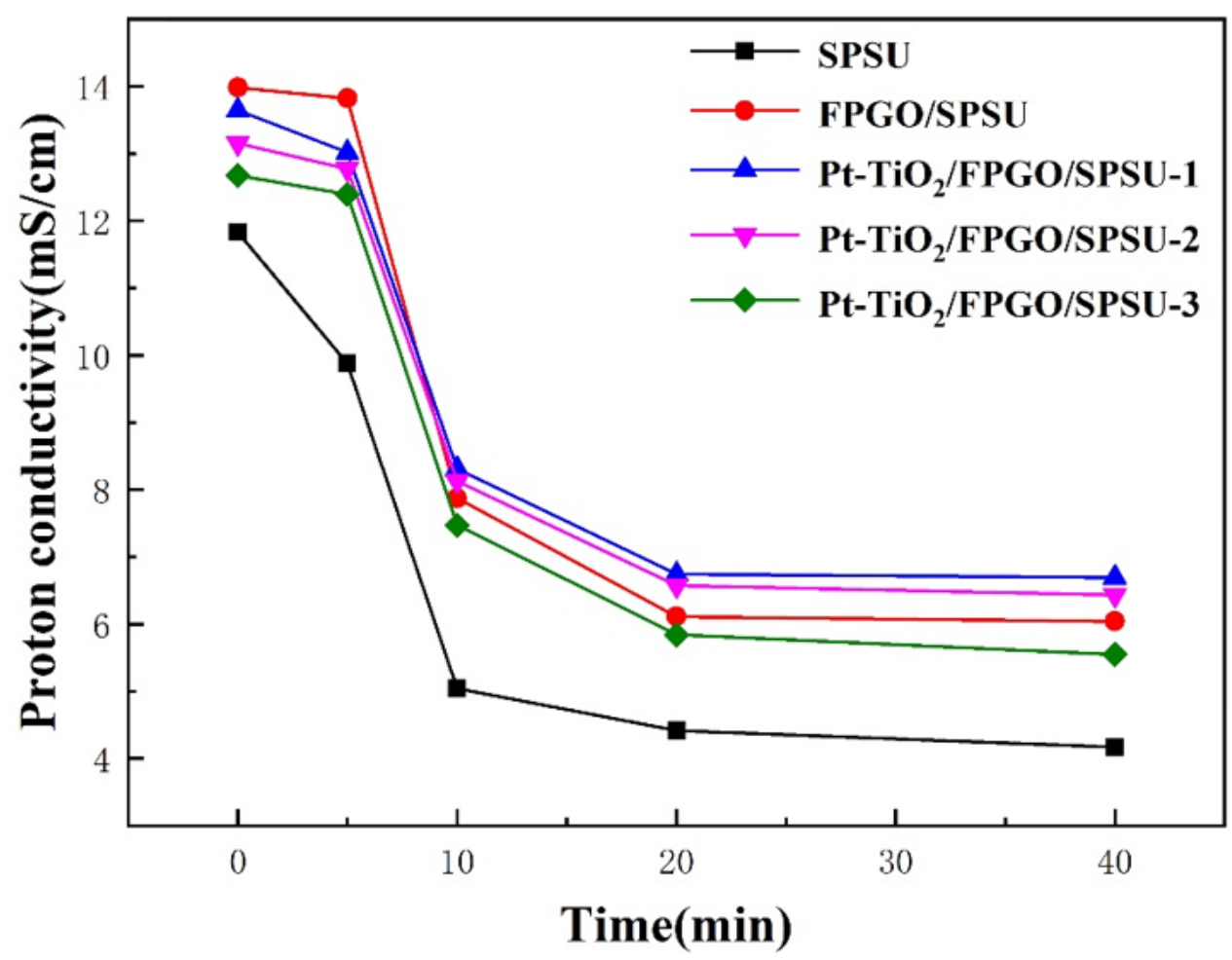

Figure 9. Proton conductivity of all the membranes at a constant temperature of $60^{\circ} \mathrm{C}$ with time.

\subsubsection{Methanol Permeability and Selectivity}

In a direct methanol fuel cell (DMFC), if the methanol on the anode side penetrates the proton exchange membrane to the cathode side, it will not only cause fuel waste and catalyst poisoning, but also bring some problems such as a drop in open circuit voltage of the battery [52]. Therefore, low methanol permeability and a higher selectivity coefficient is an inevitable requirement corresponding to the PEM used in DMFC.

Table 4 shows the methanol permeability and selectivity coefficient of Nafion 117, the primary SPSU membrane, the cross-linked PEM and the nanocomposite PEMs. The results show that under the same measurement conditions, the methanol permeabilities of Nafion 117 and the SPSU membrane are much higher than those of the cross-linked PEM and the nanocomposite PEMs. The introducing of GO polymer brushes and incorporating of $\mathrm{Pt}-\mathrm{TiO}_{2}$ nanoparticles occupy more free volume of the cross-linked PEM and the nanocomposite PEMs and inhibit the movement of polymeric segments, thereby limiting the size of ion clusters that can be used as methanol permeation channels. In addition, the methanol permeabilities of the nanocomposite PEMs increase slightly as the $\mathrm{Pt}-\mathrm{TiO}_{2}$ contents increase. This is because the dispersion of particles in the membrane decreases

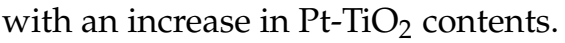

Table 4. Methanol permeability and selectivity of Nafion 117 and all the membranes.

\begin{tabular}{|c|c|c|}
\hline Membrane Samples & $\begin{array}{l}\text { Methanol Permeability } \\
\qquad\left(10^{-6} \mathrm{~cm}^{2} \mathrm{~s}^{-1}\right)\end{array}$ & $\begin{array}{c}\text { Selectivity } \\
\left(10^{4} \mathrm{~S} \mathrm{~s} \mathrm{~cm}^{-3}\right)\end{array}$ \\
\hline Nafion 117 & $2.9400^{\mathrm{a}}$ & 4.2619 \\
\hline SPSU & 2.3407 & 4.7934 \\
\hline FPGO/SPSU & 1.7117 & 7.2267 \\
\hline $\mathrm{Pt}_{-\mathrm{TiO}_{2}} / \mathrm{FPGO} / \mathrm{SPSU}-1$ & 1.4157 & 8.5117 \\
\hline $\mathrm{Pt}-\mathrm{TiO}_{2} / \mathrm{FPGO} / \mathrm{SPSU}-2$ & 1.6186 & 7.1667 \\
\hline $\mathrm{Pt}-\mathrm{TiO}_{2} / \mathrm{FPGO} / \mathrm{SPSU}-3$ & 1.6853 & 6.0879 \\
\hline
\end{tabular}

\footnotetext{
a According to ref. [53].
} 
The conductivity and methanol resistance of the membrane are two important parameters which are mutually restrictive in many cases during proton exchange. The selectivity is defined as the ratio of the proton conductivity to the methanol permeability, which intuitively reflects their relationship. It can be seen from Table 4 that the incorporation of an appropriate amount of FPGO and $\mathrm{Pt}_{-} \mathrm{TiO}_{2}$ can significantly improve the selectivity of the cross-linked PEM and the nanocomposite PEMs.

\section{Conclusions}

Based on introducing GO polymer brushes as an inorganic additive and incorporating $\mathrm{Pt}-\mathrm{TiO}_{2}$ nanoparticles fixed on polymeric PEM by forming cross-linked network structure, novel cross-linked PEM and nanocomposite PEMs with high performance and self-humidifying were prepared to solve leakage of inorganic additives during use and compatibility problem with organic polymers. Although the leakage of inorganic additives was not measured using an actual fuel cell, there is an indication that the leakage of inorganic additives may not occur based on SEM images. The introduction of GO polymer brushes into the nanocomposite PEMs exhibits a synergistic effect with the incorporating of $\mathrm{Pt}-\mathrm{TiO}_{2}$ nanoparticles overcoming the trade-off effects between proton conductivity and water retention ability, proton conductivity and methanol permeability. Proton conductivity, water uptake and methanol permeability of the nanocomposite PEM can be up to $6.93 \mathrm{mS} \mathrm{cm}^{-1}$, $46.58 \%$ and be as low as $1.4157 \times 10^{-6} \mathrm{~cm}^{2} \mathrm{~s}^{-1}$, respectively, which represent an increase of about $70 \%$, about $22 \%$ and a decrease of about $40 \%$, respectively, compared with that of primary SPSU. The study will provide a new method toward achieving high proton conductivity and water uptake as well as low methanol permeability, which has a good application prospect for direct methanol fuel cell.

Author Contributions: Conceptualization, H.R. and M.T.; methodology, T.Y., X.L., Z.X. and Z.Z.; software, X.L., Z.L., Z.X. and T.Y.; validation, X.G.; investigation, X.L.; data curation, X.L. and Z.Z.; writing-original draft preparation, X.L. and T.Y.; writing—review and editing, X.L., Z.L., T.Y., Z.X. and M.T.; visualization, X.L., X.G. and H.R.; supervision, H.R.; project administration, H.R.; funding acquisition, M.T. and H.R. All authors have read and agreed to the published version of the manuscript.

Funding: This research was funded by the Fundamental Research Funds for the Central Universities (No. 21618411).

Data Availability Statement: Not applicable.

Conflicts of Interest: The authors declare no conflict of interest.

\section{References}

1. Vinothkannan, M.; Ramakrishnan, S.; Kim, A.R.; Lee, H.K.; Yoo, D.J. Ceria stabilized by titanium carbide as a sustainable filler in the nafion matrix improves the mechanical integrity, electrochemical durability, and hydrogen impermeability of proton-exchange membrane fuel cells: Effects of the filler content. ACS Appl. Mater. Interfaces 2020, 12, 5704-5716. [CrossRef]

2. Haider, R.; Wen, Y.; Ma, Z.F.; Wilkinson, D.P.; Zhang, L.; Yuan, X.; Zhang, J. High temperature proton exchange membrane fuel cells: Progress in advanced materials and key technologies. Chem. Soc. Rev. 2021, 50, 1138-1187. [CrossRef] [PubMed]

3. Liu, Q.; Lan, F.; Chen, J.; Zeng, C.; Wang, J. A review of proton exchange membrane fuel cell water management: Membrane electrode assembly. J. Power Source 2022, 517, 230723. [CrossRef]

4. Elwan, H.A.; Mamlouk, M.; Scott, K. A review of proton exchange membranes based on protic ionic liquid/polymer blends for polymer electrolyte membrane fuel cells. J. Power Source 2021, 484, 229197. [CrossRef]

5. Zhai, L.; Li, H. Polyoxometalate-polymer hybrid materials as proton exchange membranes for fuel cell applications. Molecules 2019, 24, 3425. [CrossRef]

6. Pourzare, K.; Mansourpanah, Y.; Farhadi, S.; Sadrabadi, M.H.; Ulbricht, M. Improvement of proton conductivity of magnetically aligned phosphotungstic acid-decorated cobalt oxide embedded Nafion membrane. Energy 2022, 239, 121940. [CrossRef]

7. Pourzare, K.; Mansourpanah, Y.; Farhadi, S.; Sadrabadi, M.M.H.; Frost, I.; Ulbricht, M. Improving the efficiency of Nafion-based proton exchange membranes embedded with magnetically aligned silica-coated $\mathrm{Co}_{3} \mathrm{O}_{4}$ nanoparticles. Solid State Ion. 2020, $351,115343$. [CrossRef]

8. Tang, J.; Wan, L.; Zhou, Y.; Ye, L.; Zhou, X.; Huang, F. Synthesis and performance study of a novel sulfonated polytriazole proton exchange membrane. J. Solid State Electrochem. 2017, 21, 725-734. [CrossRef] 
9. Shabanikia, A.; Javanbakht, M.; Amoli, H.S.; Hooshyari, K.; Enhessari, M. Polybenzimidazole/strontium cerate nanocomposites with enhanced proton conductivity for proton exchange membrane fuel cells operating at high temperature. Electrochim. Acta 2015, 154, 370-378. [CrossRef]

10. Khomein, P.; Ketelaars, W.; Lap, T.; Liu, G. Sulfonated aromatic polymer as a future proton exchange membrane: A review of sulfonation and crosslinking methods. Renew. Sustain. Energy Rev. 2021, 137, 110471. [CrossRef]

11. Esmaeili, N.; Gray, E.M.; Webb, C.J. Non-fluorinated polymer composite proton exchange membranes for fuel cell applications-A review. Chem. Phys. Chem. 2019, 20, 2016-2053. [CrossRef] [PubMed]

12. Hu, Y.; Li, X.; Yan, L.; Yue, B. Improving the overall characteristics of proton exchange membranes via nanophase separation technologies: A progress review. Fuel Cells 2017, 17, 3-17. [CrossRef]

13. Gagliardi, G.G.; Ibrahim, A.; Borello, D.; El-Kharouf, A. Composite polymers development and application for polymer electrolyte membrane technologies-A review. Molecules 2020, 25, 1712. [CrossRef]

14. Di Vona, M.L.; Knauth, P. Sulfonated aromatic polymers as proton-conducting solid electrolytes for fuel cells: A short review. Z. Phys. Chem. 2013, 227, 595-614. [CrossRef]

15. Serbanescu, O.S.; Voicu, S.I.; Thakur, V.K. Polysulfone functionalized membranes: Properties and challenges. Mater. Today Chem. 2020, 17, 100302. [CrossRef]

16. Ying, Y.P.; Kamarudin, S.K.; Masdar, M.S. Silica-related membranes in fuel cell applications: An overview. Int. J. Hydrogen Energy 2018, 43, 16068-16084. [CrossRef]

17. Nor, N.A.M.; Nakao, H.; Jaafar, J.; Kim, J.D. Crosslinked carbon nanodots with highly sulfonated polyphenylsulfone as proton exchange membrane for fuel cell applications. Int. J. Hydrogen Energy 2020, 45, 9979-9988.

18. Simari, C.; Lufrano, E.; Brunetti, A.; Barbieri, G.; Nicotera, I. Highly-performing and low-cost nanostructured membranes based on Polysulfone and layered doubled hydroxide for high-temperature proton exchange membrane fuel cells. J. Power Source 2020, 471, 228440. [CrossRef]

19. Carmo, M.; Fritz, D.L.; Mergel, J.; Stolten, D. A comprehensive review on PEM water electrolysis. Int. J. Hydrogen Energy 2013, 38 , 4901-4934. [CrossRef]

20. Zhang, L.; Chae, S.R.; Hendren, Z.; Park, J.S.; Wiesner, M.R. Recent advances in proton exchange membranes for fuel cell applications. Chem. Eng. J. 2012, 204, 87-97. [CrossRef]

21. Zhang, J.; Bai, H.J.; Ren, Q.; Luo, H.B.; Ren, X.M.; Tian, Z.F.; Lu, S. Extra water-and acid-stable MOF-801 with high proton conductivity and its composite membrane for proton-exchange membrane. ACS Appl. Mater. Interfaces 2018, 10, 28656-28663. [CrossRef] [PubMed]

22. Prykhodko, Y.; Fatyeyeva, K.; Hespel, L.; Marais, S. Progress in hybrid composite Nafion ${ }^{\circledR}$-based membranes for proton exchange fuel cell application. Chem. Eng. J. 2021, 409, 127329. [CrossRef]

23. Kim, D.J.; Jo, M.J.; Nam, S.Y. A review of polymer-nanocomposite electrolyte membranes for fuel cell application. J. Ind. Eng. Chem. 2015, 21, 36-52. [CrossRef]

24. Escorihuela, J.; Narducci, R.; Compañ, V.; Costantino, F. Proton conductivity of composite polyelectrolyte membranes with metal-organic frameworks for fuel cell applications. Adv. Mater. Interfaces 2019, 6, 1801146. [CrossRef]

25. Lee, J.R.; Won, J.H.; Yoon, K.S.; Hong, Y.T.; Lee, S.Y. Multilayer-structured, $\mathrm{SiO}_{2}$ / sulfonated poly (phenylsulfone) composite membranes for proton exchange membrane fuel cells. Int. J. Hydrogen Energy 2012, 37, 6182-6188. [CrossRef]

26. Taghizadeh, M.T.; Vatanparast, M. Ultrasonic-assisted synthesis of $\mathrm{ZrO}_{2}$ nanoparticles and their application to improve the chemical stability of Nafion membrane in proton exchange membrane (PEM) fuel cells. J. Colloid Interface Sci. 2016, 483, 1-10. [CrossRef]

27. Lee, C.; Park, J.; Jeon, Y.; Park, J.I.; Einaga, H.; Truong, Y.B.; Shul, Y.G. Phosphate-modified $\mathrm{TiO}_{2} / \mathrm{ZrO}_{2}$ nanofibrous web composite membrane for enhanced performance and durability of high-temperature proton exchange membrane fuel cells. Energy Fuels 2017, 31, 7645-7652. [CrossRef]

28. Gonggo, S.T. Synthesis and characterization of sulfonate polystyrene-lignosulfonate-alumina ( $\mathrm{SPS}-\mathrm{LS}-\mathrm{Al}_{2} \mathrm{O}_{3}$ ) polyblends as electrolyte membranes for fuel cell. In AIP Conference Proceedings; AIP Publishing LLC: Melville, NY, USA, 2015; Volume 1677, p. 120009.

29. Xing, D.; He, G.; Hou, Z.; Ming, P.; Song, S. Preparation and characterization of a modified montmorillonite/sulfonated polyphenylether sulfone/PTFE composite membrane. Int. J. Hydrogen Energy 2011, 36, 2177-2183. [CrossRef]

30. Kumar, A.; Su, H.C.; Chen, Y.S.; Arpornwichanop, A. Effect of catalyst layer with zeolite on the performance of a proton exchange membrane fuel cell operated under low-humidity conditions. Int. J. Hydrogen Energy 2021, 46, 15878-15886. [CrossRef]

31. Branco, C.M.; Sharma, S.; de Camargo Forte, M.M.; Steinberger-Wilckens, R. New approaches towards novel composite and multilayer membranes for intermediate temperature-polymer electrolyte fuel cells and direct methanol fuel cells. J. Power Source 2016, 316, 139-159. [CrossRef]

32. Liu, Q.; Li, Z.; Wang, D.; Li, Z.; Peng, X.; Liu, C.; Zheng, P. Metal organic frameworks modified proton exchange membranes for fuel cells. Front. Chem. 2020, 8, 694. [CrossRef] [PubMed]

33. Cheng, T.; Zhang, X.; Ma, Y.; Huang, Y.; Liu, X. Constructing continuous proton-conducting highways within sulfonated poly (arylene ether nitrile) composite membrane by incorporating amino-sulfo-bifunctionalized GO. Polymers 2018, 10, 1005. [CrossRef] [PubMed]

34. Yang, H.C.; Hou, J.; Chen, V.; Xu, Z.K. Surface and interface engineering for organic-inorganic composite membranes. J. Mater. Chem. A 2016, 4, 9716-9729. [CrossRef] 
35. Wong, C.Y.; Wong, W.Y.; Loh, K.S.; Daud, W.R.W.; Lim, K.L.; Khalid, M.; Walvekar, R. Development of poly (vinyl alcohol)-based polymers as proton exchange membranes and challenges in fuel cell application: A review. Polym. Rev. 2020, 60, 171-202. [CrossRef]

36. Kim, D.J.; Choi, D.H.; Park, C.H.; Nam, S.Y. Characterization of the sulfonated PEEK/sulfonated nanoparticles composite membrane for the fuel cell application. Int. J. Hydrogen Energy 2016, 41, 5793-5802. [CrossRef]

37. Wu, Z.; Sun, G.; Jin, W.; Hou, H.; Wang, S.; Xin, Q. Nafion ${ }^{\circledR}$ and nano-size $\mathrm{TiO}_{2}-\mathrm{SO}_{4}{ }^{2-}$ solid superacid composite membrane for direct methanol fuel cell. J. Membr. Sci. 2008, 313, 336-343. [CrossRef]

38. Giussi, J.M.; Cortez, M.L.; Marmisollé, W.A.; Azzaroni, O. Practical use of polymer brushes in sustainable energy applications: Interfacial nanoarchitectonics for high-efficiency devices. Chem. Soc. Rev. 2019, 48, 814-849. [CrossRef] [PubMed]

39. Anahidzade, N.; Abdolmaleki, A.; Dinari, M.; Tadavani, K.F.; Zhiani, M. Metal-organic framework anchored sulfonated poly (ether sulfone) as a high temperature proton exchange membrane for fuel cells. J. Membr. Sci. 2018, 565, 281-292. [CrossRef]

40. $\mathrm{Wu}, \mathrm{D} . ; \mathrm{Xu}, \mathrm{T}$.; $\mathrm{Wu}, \mathrm{L} . ; \mathrm{Wu}, \mathrm{Y}$. Hybrid acid-base polymer membranes prepared for application in fuel cells. J. Power Source 2009, 186, 286-292. [CrossRef]

41. Kim, A.R.; Vinothkannan, M.; Song, M.H.; Lee, J.Y.; Lee, H.K.; Yoo, D.J. Amine functionalized carbon nanotube (ACNT) filled in sulfonated poly (ether ether ketone) membrane: Effects of ACNT in improving polymer electrolyte fuel cell performance under reduced relative humidity. Compos. Part B Eng. 2020, 188, 107890. [CrossRef]

42. Sun, X.; Zhang, T.; Liu, X.; Ren, H.; Zhang, Q.; Feng, Y.; Ding, H. Multi-functionalized acid-base double-shell nanotubes are incorporated into the proton exchange membrane to cope with low humidity conditions. Int. J. Hydrogen Energy 2020, 45 , 30673-30688. [CrossRef]

43. Yu, S.; Zhang, H.; Xiao, L.; Choe, E.W.; Benicewicz, B.C. Synthesis of Poly (2, 2'-(1, 4-phenylene) 5, 5'-bibenzimidazole)(para-PBI) and Phosphoric Acid Doped Membrane for Fuel Cells. Fuel Cells 2009, 9, 318-324. [CrossRef]

44. Yang, T.J.; Li, Z.L.; Lyu, H.L.; Zheng, J.J.; Liu, J.L.; Liu, F.N.; Zhang, Z.Y.; Rao, H.X. A graphene oxide polymer brush based cross-linked nanocomposite proton exchange membrane for direct methanol fuel cells s. RSC Adv. 2018, 8, 15740-15753. [CrossRef]

45. Zubir, N.A.; Zhang, X.; Yacou, C.; Diniz da Costa, J.C. Fenton-like degradation of acid orange 7 using graphene oxide-iron oxide nanocomposite. Sci. Adv. Mater. 2014, 6, 1382-1388. [CrossRef]

46. Gao, Y.; Yip, H.L.; Chen, K.S.; O’Malley, K.M.; Acton, O.; Sun, Y.; Jen, A.K.Y. Surface doping of conjugated polymers by graphene oxide and its application for organic electronic devices. Adv. Mater. 2011, 23, 1903-1908. [CrossRef] [PubMed]

47. Huang, Y.J.; Ye, Y.S.; Yen, Y.C.; Tsai, L.D.; Hwang, B.J.; Chang, F.C. Synthesis and characterization of new sulfonated polytriazole proton exchange membrane by click reaction for direct methanol fuel cells (DMFCs). Int. J. Hydrogen Energy 2011, 36, 15333-15343. [CrossRef]

48. Deng, Q.; Wilkie, C.A.; Moore, R.B.; Mauritz, K.A. TGA-FTi. r. investigation of the thermal degradation of Nafion ${ }^{\circledR}$ and Nafion ${ }^{\circledR} /$ [silicon oxide]-based nanocomposites. Polymer 1998, 39, 5961-5972. [CrossRef]

49. Mossayebi, Z.; Saririchi, T.; Rowshanzamir, S.; Parnian, M.J. Investigation and optimization of physicochemical properties of sulfated zirconia/sulfonated poly (ether ether ketone) nanocomposite membranes for medium temperature proton exchange membrane fuel cells. Int. J. Hydrogen Energy 2016, 41, 12293-12306. [CrossRef]

50. Li, P.; Dang, J.; Wu, W.; Lin, J.; Zhou, Z.; Zhang, J.; Wang, J. Nanofiber composite membrane using quantum dot hybridized SPEEK nanofiber for efficient through-plane proton conduction. J. Membr. Sci. 2020, 609, 118198. [CrossRef]

51. Li, Y.; Liang, L.; Liu, C.; Li, Y.; Xing, W.; Sun, J. Self-Healing proton-exchange membranes composed of Nafion-poly (vinyl alcohol) complexes for durable direct methanol fuel cells. Adv. Mater. 2018, 30, 1707146. [CrossRef]

52. Li, H.Q.; Liu, X.J.; Wang, H.; Yang, H.; Wang, Z.; He, J. Proton exchange membranes with cross-linked interpenetrating network of sulfonated polyvinyl alcohol and poly (2-acrylamido-2-methyl-1-propanesulfonic acid): Excellent relative selectivity. J. Membr. Sci. 2020, 595, 117511. [CrossRef]

53. Li, Y.; Hoorfar, M.; Shen, K.; Fang, J.; Yue, X.; Jiang, Z. Development of a crosslinked pore-filling membrane with an extremely low swelling ratio and methanol crossover for direct methanol fuel cells. Electrochim. Acta 2017, 232, 226-235. [CrossRef] 